\title{
土木工程造价在各个阶段的成本控制分析
}

潘奇臣

广西嘉城投资管理有限公司

DOI:10.32629/btr.v3i3.2978

[摘要] 随着我国国民经济的快速发展, 土木工程市场渐渐不再是仅为国家所开放,有一些企业也参与进来,随着大批的企业家的参与投资建筑 项目,为了获得与投资相符的利润, 就需要对土木工程项目进行科学合理的造价控制。土木工程作为一项系统性的建设性项目,势必能够涉及到 多个层次阶段,所以,在工程进行的各个阶段都要对项目进行造价成本控制,从进行工程设计到施工的各个阶段都要严格把控。

[关键词] 土木工程; 造价成本控制; 各个阶段

\section{1 土木工程中成本控制的重要性}

因为土木工程项目自身独特的情况以及规模, 使得土木工程项目成为 了一项庞大、复杂、系统的项目。要想保证整个工程项目的正常运作, 就 需要充分考虑到每个环节。在土木工程项目的成本控制过程中, 需要利用 财务跟踪、市场规律分析、项目审核、审计、提升管理技术等措施, 制定 完善的成本控制方案, 以此保证所投入的项目资金能够获得最大的回报, 所有的工作也能够顺利展开。此外, 在整个土木工程项目成本控制的过程 中, 主要涉及到以下多个阶段: 决策阶段、施工阶段、竣工验收产品阶段、 设计计划阶段, 这些阶段对工程成本都有着一定程度的影响, 因此要进行 科学的管理, 保证工程成本得以合理控制的基础。

\section{2 工程阶段进行造价成本控制的措施和要点}

2. 1 投资决策阶段的造价成本控制

在土木工程进行投资决策阶段, 造价成本管理人员就要做好充分的准 备, 针对土木工程中的地质环境、水文环境的勘察结果和技术资料的支持 下, 科学合理的设计土木工程的规模, 优化配置工程中涉及的资金、技术、 资源, 提升资源的利用率。在投资决策阶段, 要根据土木工程的建设要求和 建设目的, 整合相关的施工工艺、施工技术、使用材料, 有效地介于成本, 降低造价成本。此外, 针对土木工程投资阶段要开展必需的工程投资估算 工作, 这是投资决策工作的基础和前提。全方位地进行成本的估算, 详细估 计和准确计算土木工程中涉及的费用、开支等, 单独提列预用费, 使成本估 算能够作为土木工程后续阶段进行造价管理和成本控制的基础。

2. 2 设计阶段造价控制

决策以后, 就是工程设计环节, 而这也是土木工程建设中的关键环节。 设计合理性会直接影响到施工作业的效果。所以在设计阶段, 要将造价控 制全面落实, 合理控制各施工环节的内容, 并做到细化处理。这就要求设计 人员做好前期勘察走访工作, 结合设计、设备及材料等具体情况, 制定完善 合理的设计方案, 并对涉及到工程造价的内容进行科学计算、周密分析, 以推动施工的顺利进行, 增大经济效益。

\section{3工程施工阶段的造价控制}

根据土木工程具体施工状况, 土木工程的施工工期很长, 工程施工阶 段的施工人员流动比较大, 当土木工程施工环节出现质量问题, 势必会对 建筑工程整体质量产生不利影响。在控制土木工程造价的过程中, 要通过 科学措施逐步完善工程造价审核流程, 对工程造价方面的制度进行严格控 制。与此同时要确保设计图纸尺寸和计算尺寸完全相符。如果工程量和设 计存在一定的差异, 需要找到问题出现的原因, 采取科学措施进行解决。在
核算工程量的过程中, 首先要全面勘察施工现场地形情况, 然后通过准确 的数据计算和分析, 同时要严格审核工程变更, 保证工程变更符合施工标 准要求。避免出现成本浪费问题, 从而有效控制土木工程造价成本。

2.4竣工结算阶段的造价控制

土木工程竣工结算阶段内, 除了要按照行业标准要求开展竣工验收工 作, 还要注重资料数据收集的合理性, 以及竣工验收环节的有效性, 从而更 好的实现造价控制目标。同时在竣工结算环节内, 工作人员也需要开展全 程监督与配合工作, 对不符合行业规定或设计要求的内容, 进行及时的指 出和纠正, 避免危险的发生。另外, 还应对材料、工艺、设备等于造价相关 的内容予以严格审查, 确保其符合具体要求, 增强资金投入的合理性, 以期 减少不必要的损失, 提升工程建设的整体水平。

2.5 企业成本控制队伍的建设

无论是土木工程造价, 还是成本控制工作, 都需要高素质的经济类型 和管理类型人才。土木工程企业必须将高素质、高水平、高效能的土木工 程造价和成本管理专业队伍建设作为核心的建设目标, 确保土木工程造价 和成本在各时期和阶段得到全面、系统开展。土木工程企业要建立成本和 造价管理控制队伍, 重视土木工程造价人才的选拔、培训和发展机制, 定期 对土木工程造价人才的技能和专业能力进行再教育。同时, 建立土木工程 成本控制人员的激励机制和薪酬系统, 扩展他们的发展空间和提升环境, 使土木工程企业留住更多、更好、更专业的土木工程造价和成本控制人员, 在队伍和素质上真正实现高效率, 控制好土木工程造价和成本。

\section{3 结语}

随着国民经济的不断发展, 为了有效的适应现代化发展的需求, 建筑 企业要做好工程管理和造价控制方面的措施, 为企业创造更大的经济利益, 在土木工程施工过程中, 最为重要的问题就是工程造价, 只有有效的控 制工程施工成本, 才能确保土木工程的顺利实施。目前, 我国的土木工程 造价管理工作还存在一定的问题, 需要制定出合理的造价管理方案, 确 保建筑工程项目资金充足的基础上, 落实节约成本措施, 不断提升工程 的经济效益。

\section{[参考文献]}

[1]王彦荣.土木工程造价各阶段成本控制探究[J].门窗,2019(13):207-208.

[2]刘磊.探讨土木工程造价在各个阶段的成本控制[J].科技创业 家,2014(06):47.

[3]吴琼.关于土木工程造价成本控制的各个阶段的探讨 [ J . 城市建设 理论研究(电子版),2017(31):192. 